\title{
MCFC Product Development Test
}

\author{
Annual Report \\ October 1, 1995 - September 30, 1996
}

Work Performed Under Contract No.: DE-FC21-92MC29237

\author{
For \\ U.S. Department of Energy \\ Office of Fossil Energy \\ Federal Energy Technology Center \\ Morgantown Site \\ P.O. Box 880 \\ Morgantown, West Virginia 26507-0880
}

By

Fuel Cell Engineering Corporation

3 Great Pasture Road

Danbury, Connecticut 06813

IISTRIBUTION OF TMIS DOCUMENT IS UNLIMITED 


\section{Disclaimer}

This report was prepared as an account of work sponsored by an agency of the United States Government. Neither the United States Government nor any agency thereof, nor any of their employees, makes any warranty, express or implied, or assumes any legal liability or responsibility for the accuracy, completeness, or usefulness of any information, apparatus, product, or process disclosed, or represents that its use would not infringe privately owned rights. Reference herein to any specific commercial product, process, or service by trade name, trademark, manufacturer, or otherwise does not necessarily constitute or imply its endorsement, recommendation, or favoring by the United States Government or any agency thereof. The views and opinions of authors expressed herein do not necessarily state or reflect those of the United States Government or any agency thereof. 


\section{DISCLAIMER}

Portions of this document may be illegible electronic image products. Images are produced from the best available original document. 
TABLE OF CONTENTS

1.0 INTRODUCTION

1

2.0 PROJECT OVERVIEW

1

2.1 Project Objectives

1

2.2 Project Background

1

2.3 Project Description

.3

3.0

PROJECT RESULTS

8

3.1 Task 1 - MANAGEMENT PLAN AND ENVIRONMENTAL INFORMATION 9

3.2 Task 2 - DESIGN OF A FULL-SCALE MCFC POWER PLANT

9

3.3 Task 3 - MANUFACTURE AND ASSEMBLE FUEL CELL STACK MODULES 9

3.4 Task 4 - ACQUISITION OF BALANCE OF PLANT (BOP PROCUREMENT) 15

3.5 Task 5 - PREPARATION/ACQUISITION OF POWER PLANT TEST SITE 15

3.6 Task 6 - POWER PLANT TESTING 17

4.0 SUMMARY

23 
Page 1

\subsection{INTRODUCTION}

This is the fourth annual report covering progress made under DOE cooperative agreement DE-FC21-92MC29237, Molten Carbonate Fuel Cell Product Development Test. The project is for the design, construction, and testing of a $2 \mathrm{MW}$ carbonate fuel cell power plant in the City of Santa Clara, California, and the period covered in this fourth annual report is October, 1995 to September, 1996. The report is divided into sections which describe the progress in various program activities. Section 2.0 provides an overview of the program, including the project objectives, site location, and schedule. Section 3 presents a summary by Task of the progress achieved in this fourth year of the program.

\subsection{PROJECT OVERVIEW}

\subsection{Project Objectives}

The objective of the project is the demonstration of the carbonate fuel cell technology at full scale. The carbonate fuel cell is a power generation technology which has the potential for significant benefits in terms of reduced dependency on foreign fuels and reduced greenhouse and acid rain emissions. However, in order for utilities to adopt the technology into their generation mix, it is essential that it be demonstrated at the multi-megawatt level. The Santa Clara Demonstration Project is the first such demonstration plant for the carbonate technology. Additional objectives of the project include the demonstration of specific advantages of the carbonate fuel cell power plant, such as high efficiency, low emissions, reactive power capability, and high reliability, availability, and durability. The project also provides design input for pre-commercial power plants, and is an important step in the commercialization of the carbonate fuel cell.

\subsection{Project Background}

The project is an outgrowth of the ongoing carbonate technology development work and commercialization efforts at Energy Research Corporation (ERC, parent company to Fuel Cell Engineering Corporation). ERC is working with the Fuel Cell Commercialization Group (FCCG) in a collaboration to commercialize the carbonate fuel cell technology in the late 1990's. The FCCG is a group of utilities who are potential buyers of the first commercial power plants. A commercialization path has been identified which includes the demonstration of the technology in power plants prior to the beginning of commercial power plant manufacturing. The Santa Clara Plant is the first of these demonstrations, and the project's utility participants have been drawn from the FCCG membership. The participants in the Santa Clara Demonstration 
Project (SCDP) are as follows: City of Santa Clara, City of Los Angeles Department of Water and Power, City of Vernon, Electric Power Research Institute, National Rural Electric Cooperative Association, Sacramento Municipal Utility District, and Southern California Edison Company. Salt River Project and the Northern California Power Agency (NCPA) are also supplying some project funding through a consortium agreement with the City of Santa Clara. In addition, the California Energy Commission provided funding to partially support the Balance of Plant Pre-Test activities.

A critical step in ERC's commercialization effort was the formation of two subsidiaries in 1990: The Fuel Cell Manufacturing Corporation (FCMC) and the Fuel Cell Engineering Corporation (FCE). FCMC manufactures carbonate stacks and multi-stack modules, currently from it's manufacturing facility in Torrington, CT and eventually from a commercial scale manufacturing facility. FCE is responsible for power plant design, integration of all subsystems, sales/marketing, and client services.

The demonstration project is being funded by the SCDP, the U.S. Department of Energy under the Cooperative Agreement, and ERC/FCE. FCE is providing over all management of the project. The stack design has being developed by ERC based on technology from separate ongoing development programs. The stacks were fabricated by ERC's manufacturing subsidiary, FCMC. Fluor Daniel, Inc. (FDI) served as the power plant A\&E, provided engineering support for the design of the multi-stack fuel cell modules, and is providing technical support during the test phase.

FCE began work on the Santa Clara demonstration power plant design in 1990, and submitted a preliminary design to the SCDP in August, 1991. A series of studies were conducted to optimize the design over the next year, and Final Engineering began in * September, 1992. The design of the multi-stack modules used in the DC power section of the plant was begun earlier under EPRI and ERC support. The DOE supported portion of the project began in October, 1992. The work scope of the DOE funded portion of the project includes:

- The development of environmental information to support the DOE NEPA process.

- The development of the final design of the multi-stack modules used in the DC power section of the plant.

- The manufacture of the fuel cell stacks and multi-stack modules for the plant. 
The status of these activities and activities in the cost shared portion of the project are discussed in Section 3, after an overall description of the power plant.

\subsection{Project Description}

The site for the plant is located at 1255 Space Park Drive in the City of Santa Clara. The site is owned by the City's Electric Department and is immediately adjacent to the Scott Receiving Station, a 115/60kV switching station on the City electrical system. The demonstration plant occupies a portion of the site, measuring approximately 150 by 150 feet. An area of similar size immediately adjacent to the site was made available as laydown area during plant construction.

The power plant uses 16 fuel cell stacks, each rated at $125 \mathrm{~kW}$. The stacks were delivered to the site in truck-shippable 4-stack submodules, which were installed into two $1 \mathrm{MW}$ modules to comprise the DC power section of the plant. The power plant process is ERC's Simplified Design, which includes provision for startup, fuel cleanup, recirculation of carbon dioxide to the cathode side and exhaust of spent gases.

The process involves treating natural gas to remove impurities, after which it is mixed with steam and sent to the fuel cell stacks. The fuel/steam mixture is reformed in the stacks, providing the hydrogen which is consumed in the fuel cell anodes. The anode reaction also produces $\mathrm{CO}_{2}$, which is required in the fuel cell cathodes. The cathode feed is produced by taking the anode exhaust, catalytically reacting any residual fuel with air, and sending the flue gas with excess air to the cathodes. A simplified process flow diagram is shown in Figure 2.1.

As shown in the Figure 2.1, the natural gas fuel is preheated by exchanging heat with cathode exhaust gases in E-103. The gas is then sent through the fuel processing system, in which sulfur odorants and other impurities are removed. The treated gas is mixed with steam, and the fuel/steam mixture is brought up to the required fuel cell temperature in $\mathrm{E}-101$, the final superheater. The 1100 to $1250^{\circ} \mathrm{F}$ gas is then sent to the fuel inlet headers of the $1 \mathrm{MW}$ modules. The fuel is internally reformed to hydrogen in the fuel cell stacks, and $75 \%$ of the hydrogen is consumed in the power generation reactions of the fuel cell anodes, producing water and $\mathrm{CO}_{2}$. The anode exit stream consists of this steam and $\mathrm{CO}_{2}$, carbon monoxide from the reforming and shift reactions, plus the $25 \%$ residual hydrogen. The exit stream is sent to the anode exhaust oxidizer, $\mathrm{H}-101$, where the hydrogen and carbon monoxide are catalytically combusted with excess air. 
This quenched flue gas stream now contains the oxygen and $\mathrm{CO}_{2}$ required by the fuel cell cathodes, and it is sent back to the fuel cells as the cathode feed stream. The quench air used in the anode exhaust oxidizer is adjusted to provide the desired temperature for use in the fuel cell cathodes. Once the flue gas has been quenched to this temperature $\left(\sim 1100^{\circ} \mathrm{F}\right)$, more than enough oxygen has been mixed in to supply the cathode oxygen consumption reaction. The anode exhaust oxidizer is a catalytic reactor (with a thermal section for start-up and off-design operating modes) which reacts the anode exhaust gas with no measurable $\mathrm{NO}_{x}$ production.

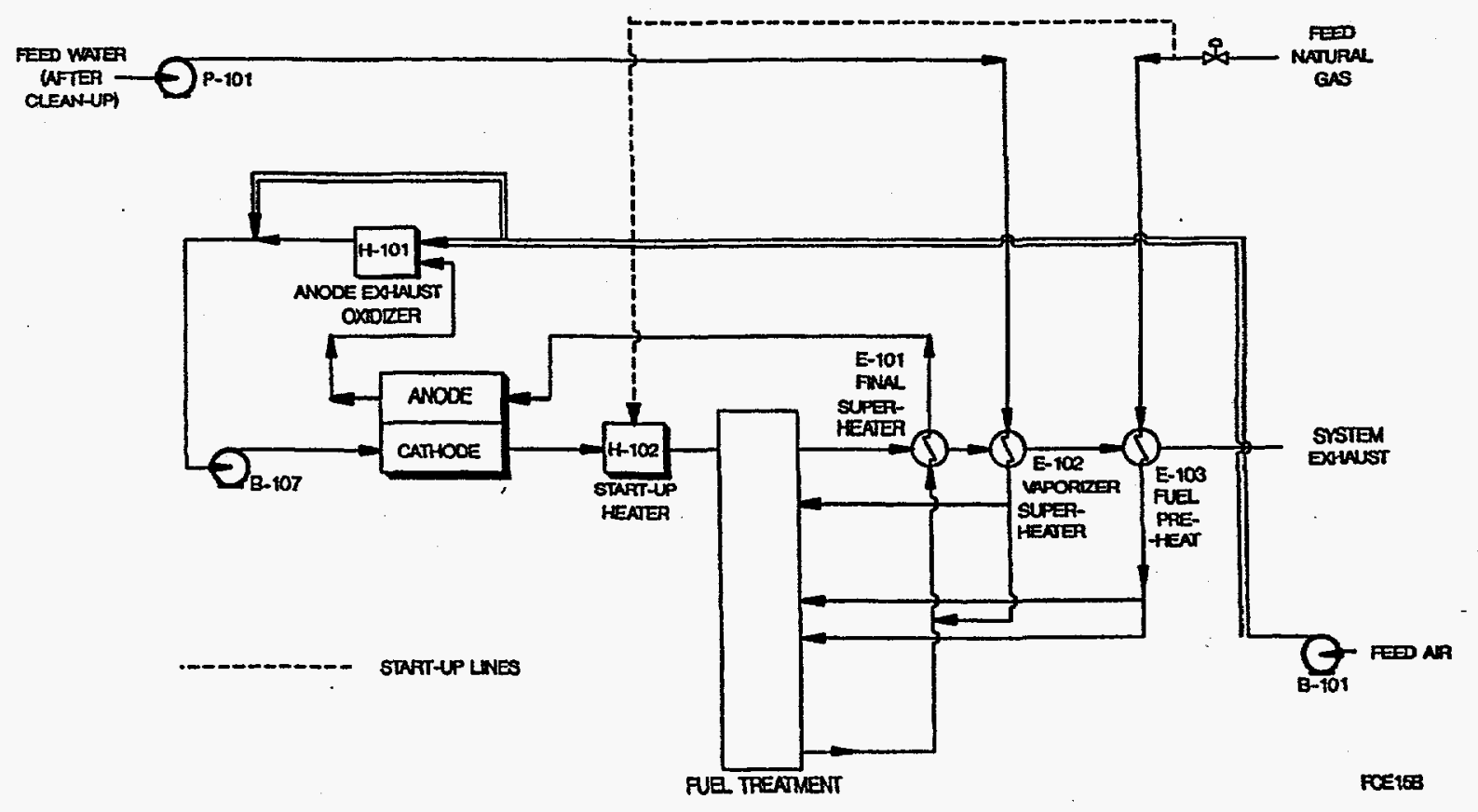

FIGURE 2.1

2MW SCDP POWER PLANT SIMPLIFIED PROCESS FLOW DIAGRAM 
Cathode exit gases are used to provide heat to the HDS reformer (R-102), the fuel/steam heater (E-101), water boiler/superheater (E-102) and the fuel preheater. These heat exchangers are configured into a packaged heat recovery unit (HRU), which also contains the start-up burner $(\mathrm{H}-102)$ and the system exhaust stack. The cathode exit gas is the shell side gas in all of the exchangers, with water, steam, or fuel in the tube side streams. The packaged HRU skid also houses the deaerator for the steam generator.

In addition to the systems described above, other subsystems in the plant include the water treatment system, instrument air compressor, backup power generator, and an auxiliary nitrogen/air gas heater for use during the first power plant start-up.

The mechanical layout of the plant is shown in Figure 2.2. The plot plan shows the location of the major equipment shown in the process flow diagram, plus additional storage facilities and equipment.

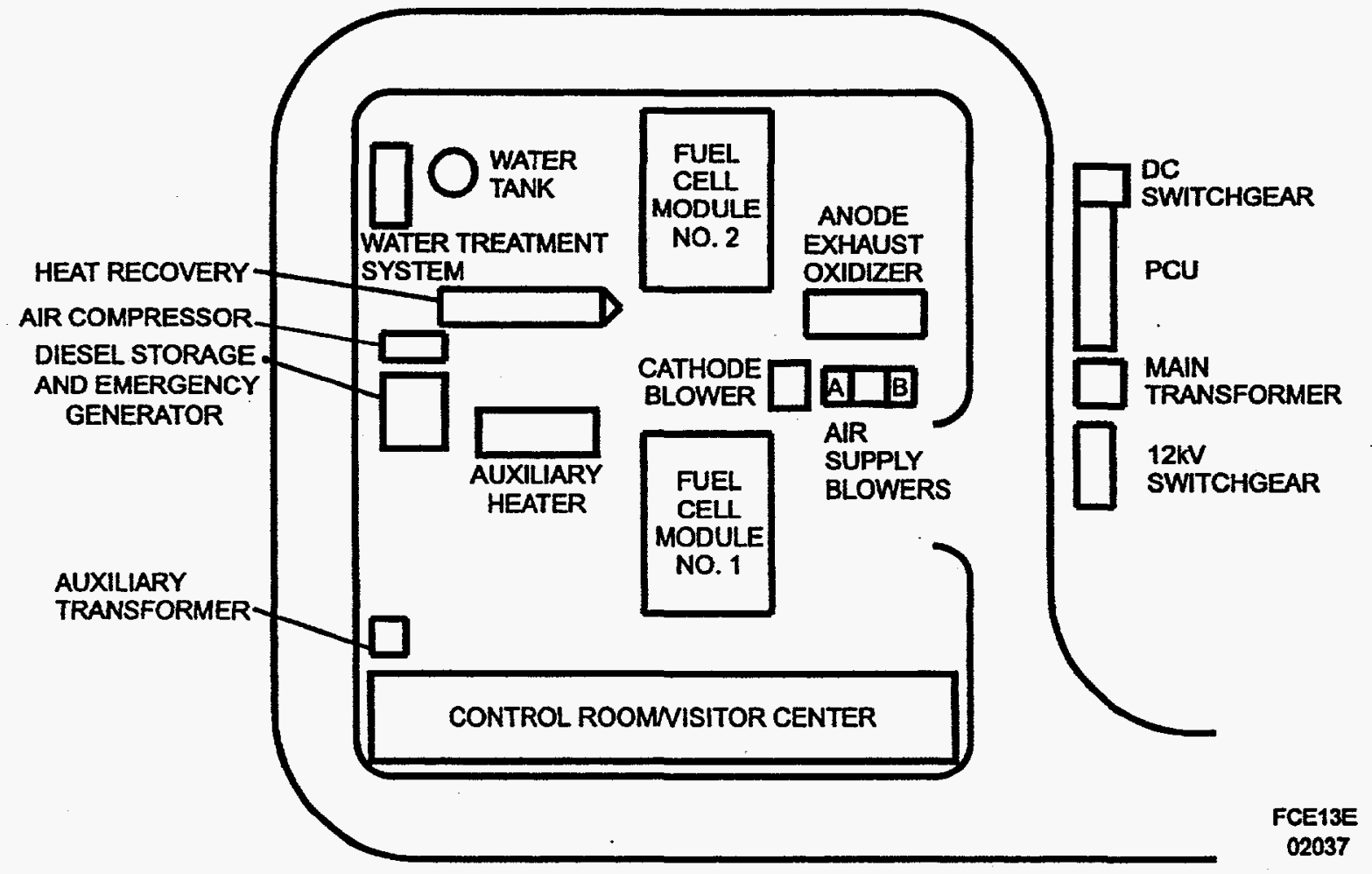

FIGURE 2.2

2MW SCDP POWER PLANT LAYOUT 
As seen in Figure 2.2, the DC power section of the plant consists of two 1MW Stack Modules. Each of these Modules contains two 4-stack submodules and associated interconnect piping and instrumentation. The basic cell and stack configuration has been developed in different technology development programs at ERC. Under the Cooperative Agreement, stack hardware design details were developed which were needed to provide the required process and mechanical interfaces in multi-stack submodules.

The carbonate fuel cell stack is the building block repeating unit of the fuel cell system. The SCDP stacks consist of 258 electrochemical cells and ancillary clamping, manifolding and electrical connection hardware. The electrochemical cells are similar to batteries in that they consist of anode and cathode (negative and positive) electrodes. Consumption of fuel occurs in the fuel cell anodes, which consume the hydrogen and carbon monoxide produced by reforming the natural gas fuel. Consumption of oxidant $\left(\mathrm{O}_{2}\right.$ and $\left.\mathrm{CO}_{2}\right)$ occurs in the cathodes. Both electrodes have catalytic surfaces over which gas is circulated. The anode and cathode catalytic layers are separated by a porous matrix material filled with molten carbonate salts. The stack operates at 1000 to $1260{ }^{\circ} \mathrm{F}$ in order to keep the carbonate salts in the liquid state.

Each cell package (anode/matrix/cathode) has a projected output of 0.762 volts at 630 amps at rated operating conditions. 258 cells are configured in a "stack" in which the cells are electrically in series, providing 197 volts at 630 amps, or $124 \mathrm{~kW} \mathrm{DC}$ power. The total 16-stack system gross DC power at rated conditions is $1.98 \mathrm{MW}$, with a net AC output of $1.8 \mathrm{MW}$.

The SCDP fuel cell stacks have been configured into multi-stack, truck shippable submodules. Each submodule consists of four stacks and associated piping, instrumentation, and electrical components in a sealed enclosure which operates at a slightly elevated pressure (up to $1 \mathrm{psig}$ ). By operating the submodules at an elevated pressures, the stack process gas flow pressures can be higher without increasing the pressure differential across the stack manifold seals. This provides sufficient pressure for the stack exhaust gases to flow through the heat recovery unit without a system exhaust blower. The overall dimensions of the 4-stack submodules are 9'-3.75" wide by $11^{\prime}-11.5^{\prime \prime}$ high by $37^{\prime}-4^{\prime \prime}$ long. All electrical and instrument connections are brought to terminal boxes on the outside of the enclosure. This design approach provided for installation of the submodules at the Santa Clara site with a minimum of field labor.

As noted above, two of these 4-stack submodules are installed into each of the two $1 \mathrm{MW}$ Modules. The $1 \mathrm{MW}$ Modules consist of these submodules and associated gas 
distribution piping, instrumentation connections, and electrical connections. The configuration of the 1MW Fuel Cell Module can be seen in Figure 2.3, which shows a the layout of one of the two $1 \mathrm{MW}$ modules.

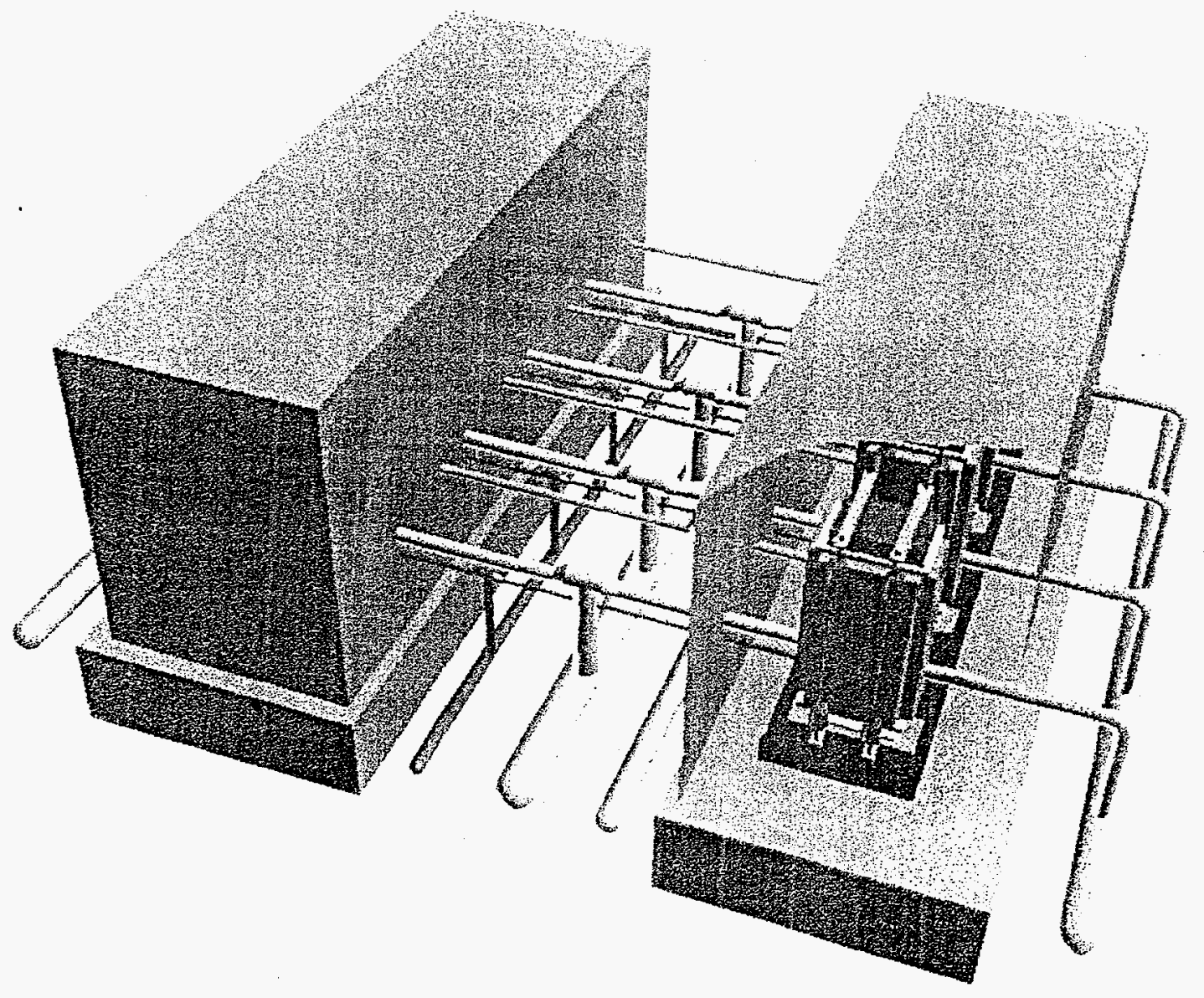

FIGURE 2.3

1MW FUEL CELL MODULE CONFIGURATION 
Page 8

\subsection{PROJECT RESULTS}

A summary level project schedule is shown in Figure 2.1. Activities in this fourth year of the program included the completion of the stack and stack submodule fabrication effort, the installation of submodules into the power plant, and the initial testing of the power plant. The following sections describe the results of project activities by task in the fourth year.

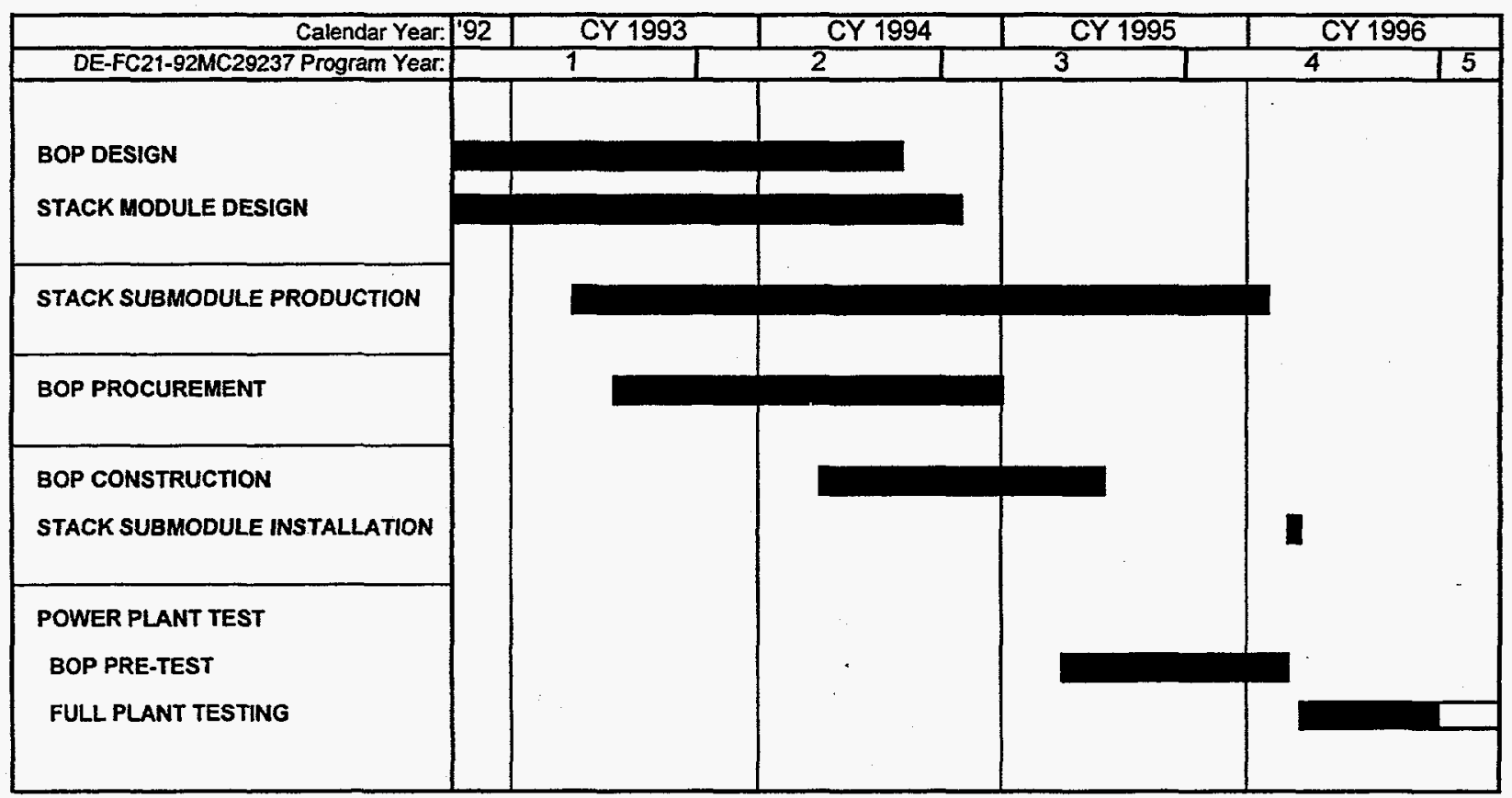

FIGURE 2.1

PROJECT SUMMARY LEVEL SCHEDULE 
Page 9

\subsection{Task 1 - MANAGEMENT PLAN AND ENVIRONMENTAL INFORMATION} The project Management Plan was prepared in the first month after project award, and submitted in November, 1992. The Environmental Information Topical Report was prepared in the form of a draft Environmental Assessment document on a pre-award basis. The report was submitted in May, 1992, to support the DOE submittal of an Environmental Assessment for the National Environmental Policy Act (NEPA) approval. NEPA approval was obtained in February, 1993.

Prior to this DOE supported environmental work, the Bay Area Air Quality Management District had granted the project an exemption from Air Quality permitting requirements. Also, under the California Environmental Quality Act (CEQA) a Negative Declaration was issued, indicating that no significant environmental impact is anticipated, and a Conditional Use Permit was issued.

During the third year of the project, all local construction and operating permits were obtained with the exception of the final phase occupance permit. The occupancy permit was issued in two stages, with the first stage issued upon completion of the balance of plant construction. The second phase of the permit was issued during this fourth year, following installation of the fuel cell stack submodules into the plant. The only ongoing permit activities consist of ongoing compliance work (e.g. OSHA), and annual inspection and permit renewal for operation of the instrument air compressor and steam generator.

\subsection{Task 2 - DESIGN OF A FULL-SCALE MCFC PRODUCT DEVELOPMENT TEST POWER PLANT}

Power plant design activity in this fourth year was limited to on-site markups of the design drawings to track as-built status during any modifications during the plant testing. Formal issue of final as-built drawings will occur in the fifth year of the program.

\subsection{Task 3 - MANUFACTURE AND ASSEMBLE FUEL CELL STACK MODULES}

The stack module fabrication effort was completed in this reporting period. This effort included completion of the stack fabrication work which began with the production of 
repeating components in the first year of the program. Fabrication of stack assemblies from these components began in the third year of the program and was completed in this reporting period in January, 1996. A view of several stacks in the FCMC final assembly area is shown in Figure 3.1.

The fabrication of multi-stack enclosures was done by a southern California subcontractor. The enclosures were shipped from California to FCMC's Torrington facilities on standard flatbed trucks. Once the enclosures were rigged into FCMC's work area the next step involved removal of four sections on one of the enclosure sides (which had been temporarily installed by the vendor for shipment) to allow access for fabrication activities.

Wiring and instrumentation conduits and terminations were then installed by FCMC and a local electrical contractor. At this point the stacks were rigged into their enclosure bays and mechanically installed. The enclosure sides were reinstalled and permanently sealed, and penetration feedthroughs were then attached providing the connection from the stack manifold piping through the enclosure walls to the point where the BOP would be connected in the field. The submodules were then sealed using four removable hatches on the top of the enclosure (one above each stack, which allow for stack removal or personnel access if necessary).

Figure 3.2 shows enclosure rigging activity at FCMC. A recently arrived enclosure is being lifted in preparation for rigging into the building, while a second unit can be seen behind it. The four enclosures were delivered to FCMC between May and September, 1995. Figure 3.3 shows an enclosure after being set into the work area, and Figure 3.4 shows stacks being installed into the third enclosure. The wiring and instrumentation conduit which had previously been installed can be seen in the back of Figure 3.4.

Completed multi-stack submodules were shipped from Torrington to Santa Clara by truck, using vehicles with provision for heavy loads (extra axles), air ride suspension, and special permitting. The first 4-stack submodule shipment arrived at the site in early November, 1995 and the fourth unit was delivered in February, 1996. During this time period the balance of plant pre-test work was ongoing, and the stacks were offloaded to temporary dunnage in the laydown area. The stacks were rigged off the dunnage and installed in the plant once the BOP pre-test was complete. 


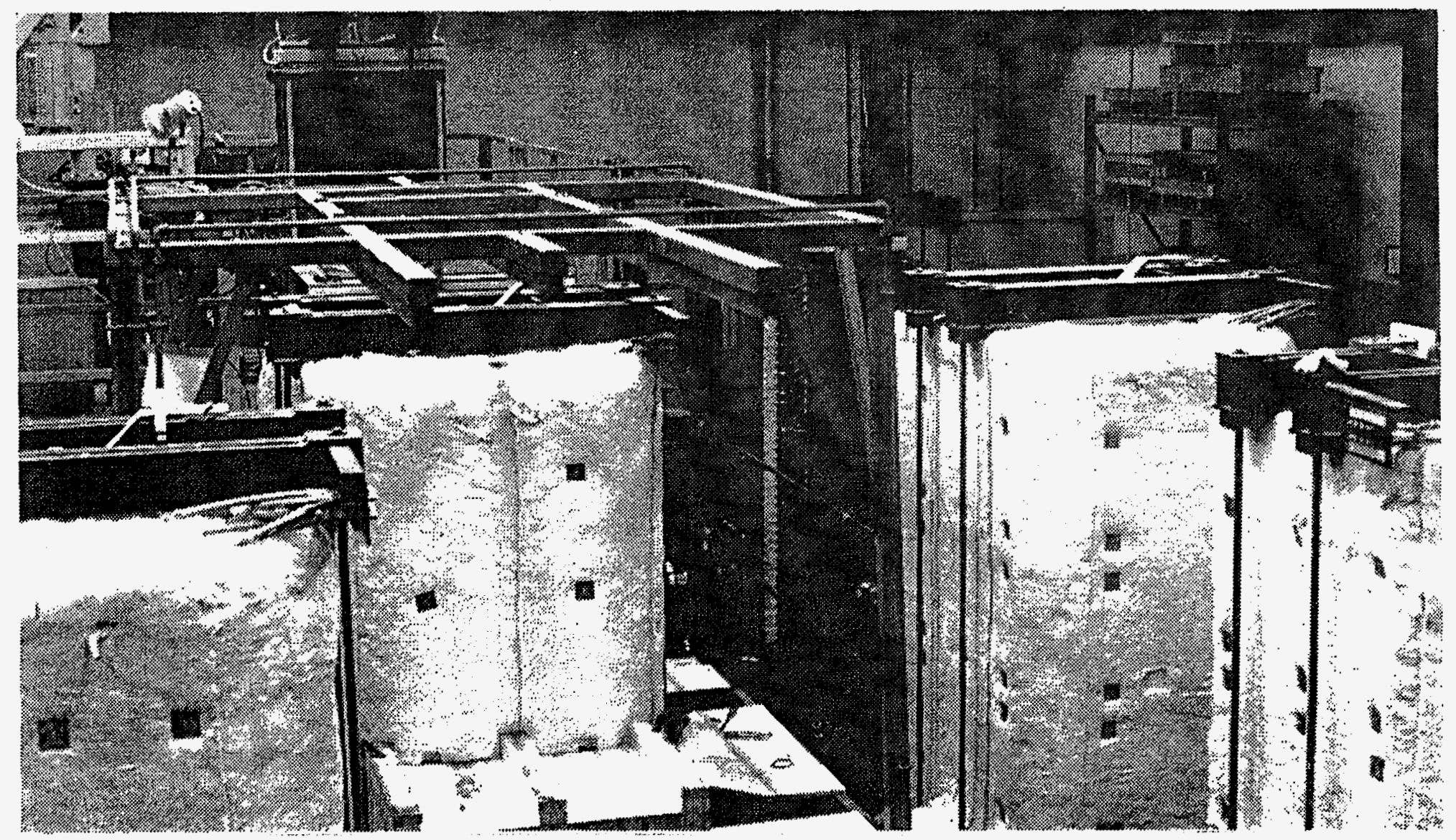

FIGURE 3.1

STACK PRODUCTION ACTIVITY AT FCMC DURING SCDP PRODUCTION RUN

A Total of 16 Stacks Were Produced at FCMC's Torrington Facility for the Demonstration Plant 


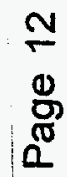
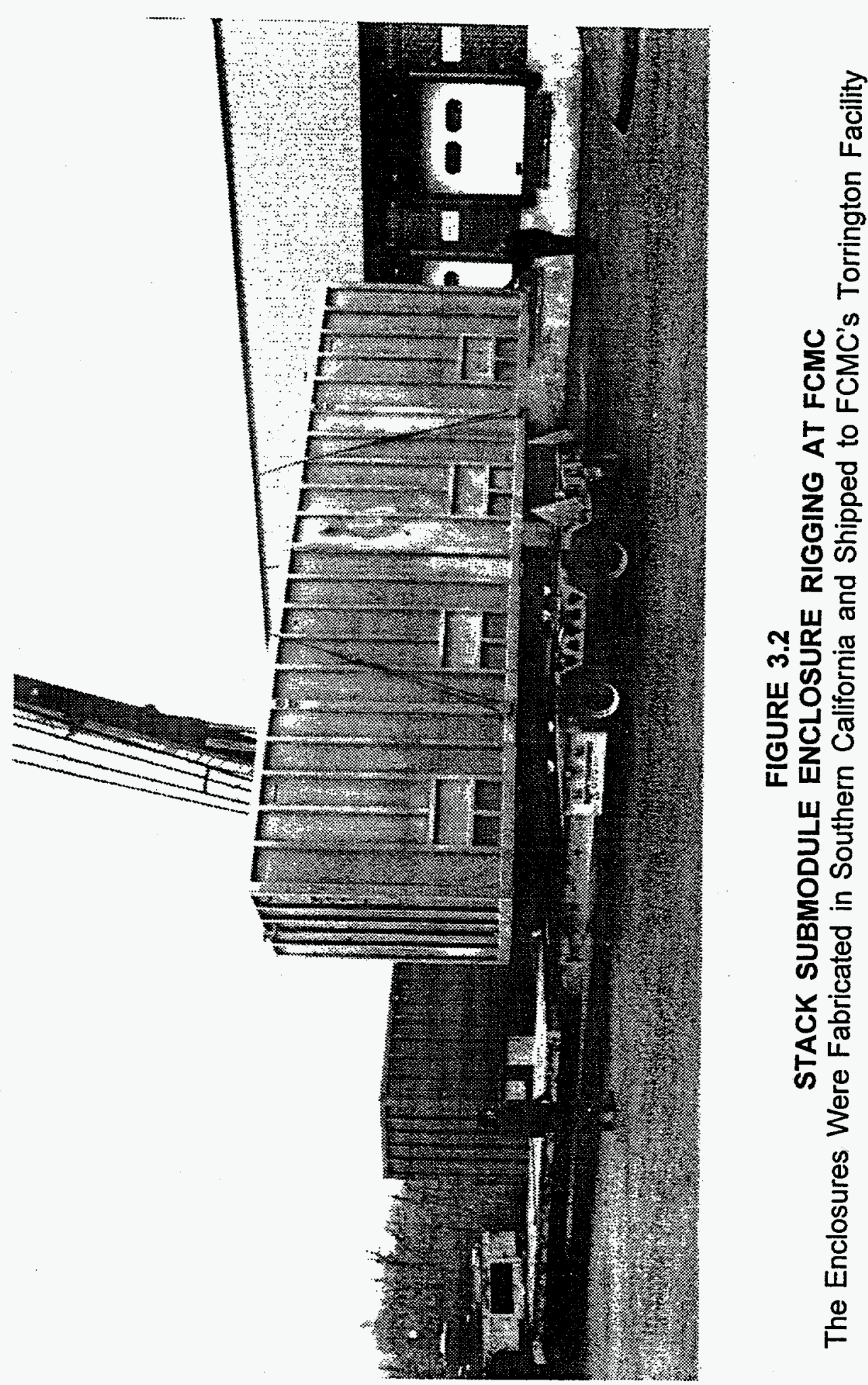


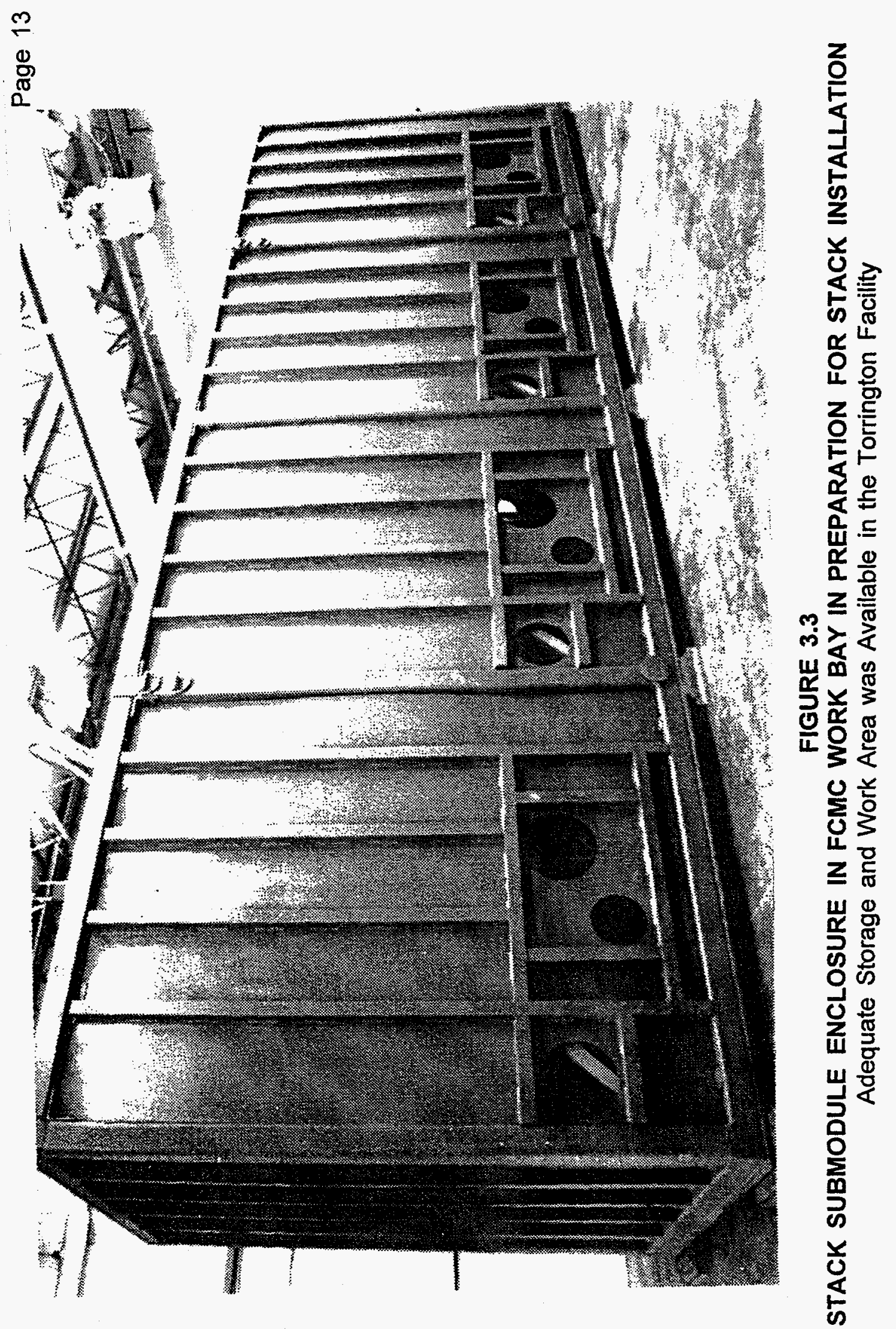




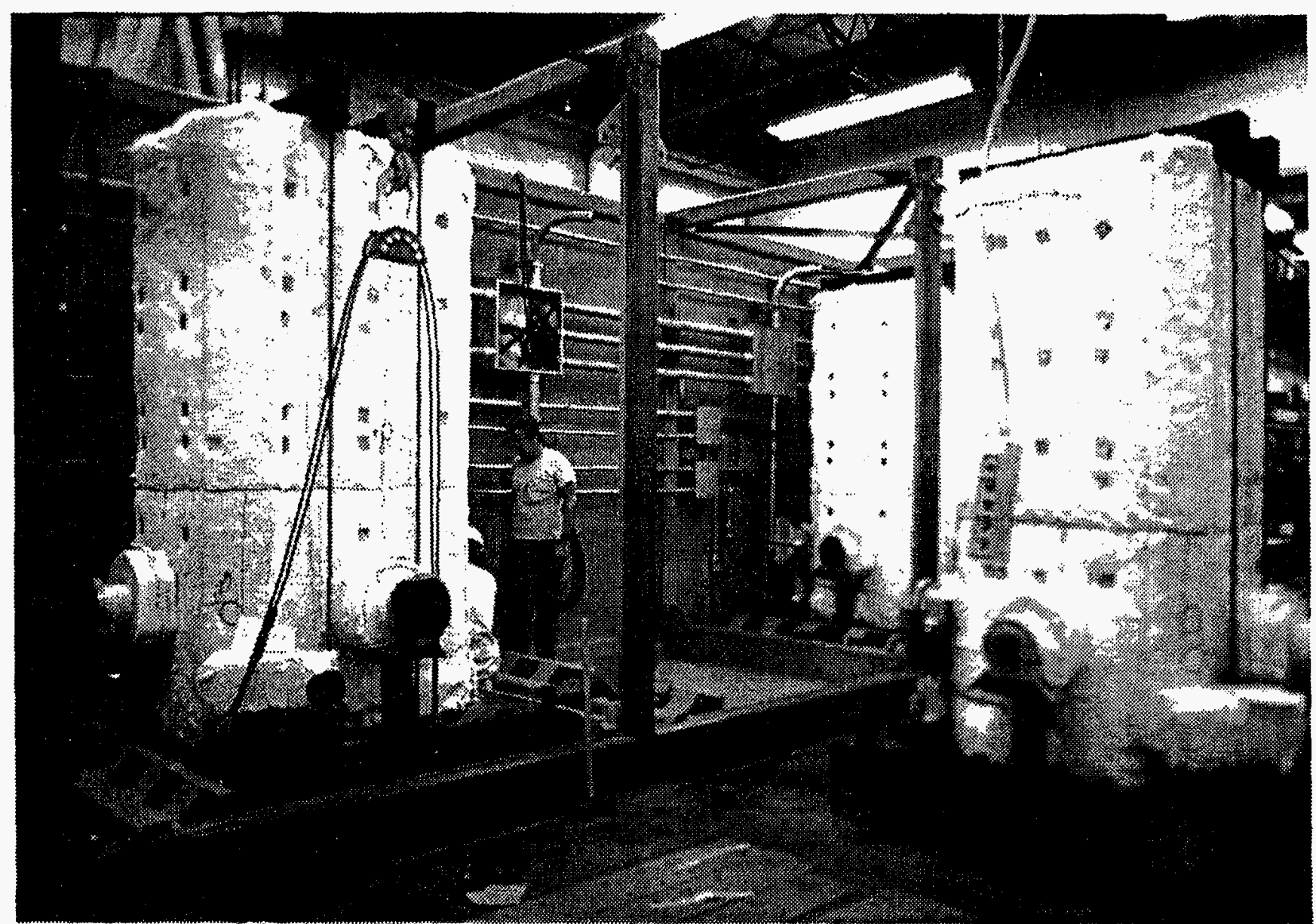

FIGURE 3.3

STACK INSTALLATION INTO 4-STACK SUBMODULE AT FCMC

Electrical and Instrumentation Conduit Runs Seen in the Background had been Installed Earlier at FCMC 
Page 15

3.4 Task 4 - ACQUISITION OF BALANCE OF PLANT (BOP PROCUREMENT) No balance of plant procurement work was done in this reporting period. BOP procurement activities began in June, 1993 with the development of RFQ's for major BOP equipment. Release of vendors for material procurement occurred in midJanuary, 1994. Most of the BOP equipment items had been delivered to the site by October, 1994. The last equipment item - the Auxiliary Nitrogen/Air Heater - was delivered in January, 1995.

\subsection{Task 5 - PREPARATIONIACQUISITION OF POWER PLANT TEST SITE (POWER PLANT CONSTRUCTION)}

BOP construction activities were completed in June, 1995. The site construction effort was initiated in April, 1994 with the formal project groundbreaking. At that point FDI was mobilizing their site staff and had recently installed their temporary construction trailer and utilities. The construction effort was paced primarily by the delivery of BOP equipment items. The last item was delivered to the site in January, 1995 forcing final piping and insulation work into February. BOP construction was essentially complete in March 1995, however resolution of outstanding subcontractor punch list items and completion of the plant insulation resulted in formal BOP Mechanical Completion occurring in the first week of June, 1995. FDI progressed through much of the construction effort under budget, however the schedule extension due to late delivery of the last BOP equipment item and the delayed punchlist resolution effort eroded those savings, and the BOP construction work was completed close to the project budget developed in May, 1993. The plant was put through a sequence of balance of plant pre-tests (see below) between BOP completion and the installation of the stack submodules.

The submodule installation effort consisted of removing pipe spool pieces used in place of the stacks during the BOP pre-test, rigging of stacks from their temporary storage dunnage to their plant foundations, and the mechanical, electrical, and instrumentation hookups to the plant. The stack installation effort took about one week and was done in early March, 1996. Figure 3.7 is an overview of the site at the completion of full plant construction and stack installation. 
$\frac{0}{\mathscr{0}}$

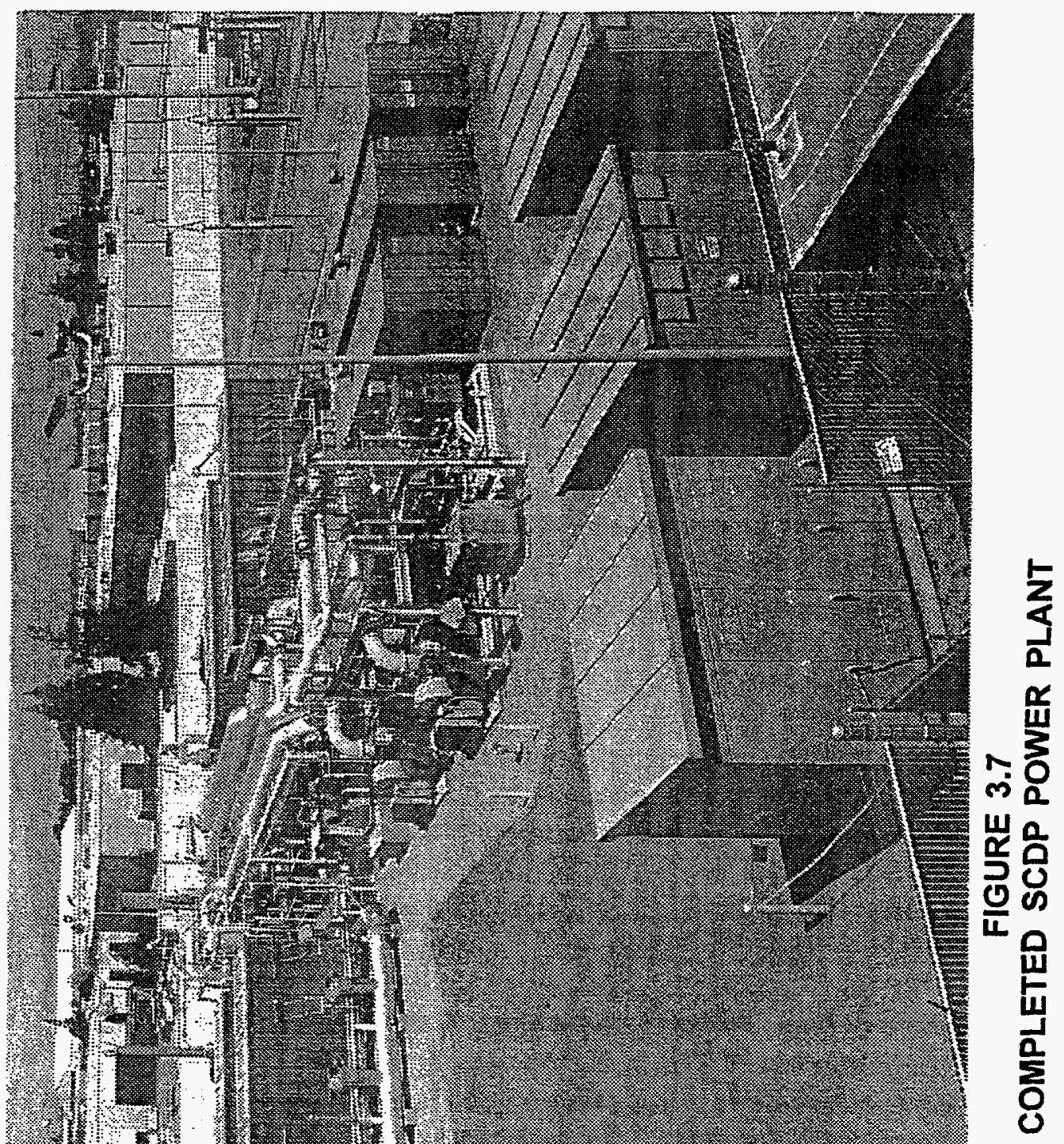


Page 17

\subsection{Task 6 - POWER PLANT TESTING}

The power plant operating staff was in place and trained by April, 1995. The operating staff consists of a plant superintendent, a plant engineer, two technicians, and around the clock staffing with locally hired power plant operators (two per shift). Beginning in April, 1995 (as individual subsystems were beginning to be turned over to FCE), and for a period lasting almost one year, the BOP system and individual equipment items were tested in a BOP pre-test effort. The BOP pre-testing thoroughly evaluated the critical plant subsystems and the plant as a whole before the stacks were installed into the system. The tests evaluated the entire plant in a series of eight "hot test" periods. The BOP pre-test effort identified and corrected a number of minor BOP problems, (e.g. leaking valve seals, etc.) as well as some major issues. These major issues included unstable performance of the anode exhaust oxidizer (pressure surging), inverter nuisance trips, insulation integrity, and air blower performance. All of the major issues were resolved before the eighth and final hot test, in which system start-up, load ramp, and trip procedures were simulated without any major system problems. The pre-test effort was concluded in this reporting period, in February, 1996. The stack submodules were then installed and the plant was ready for the initial heatup.

The initial start-up of the plant included a number of steps meant to condition the new fuel cell stacks. As delivered to the site, the stacks had not yet been heated up or operated. The first heatup of these stacks included processes related to oxidation of nickel catalyst used in the cathodes, and the consumption of binders used in the production of the fuel cell matrices. For the demonstration project, the conditioning of the sixteen stacks on-site was deemed cost effective and could be done with less schedule impact than conditioning the stacks at FCMC or ERC facilities.

The conditioning process requires careful control of the gas compositions and flow rates, particularly during the cathode nickel oxidation step. The SCDP plant included an Auxiliary Nitrogen/Air Heater which allowed the required close control of oxidant gas composition. The heater is a natural gas fired indirect heater, which can be fed with a controlled mixture of air and pipeline nitrogen. The heater was the primary source of hot gas in the system through the cathode nickel oxidation step.

The removal of matrix binder materials occurs before the oxidation phase. The matrix conditioning is a mixture of exothermic and endothermic reactions, and the net thermal impact is not as significant as the heat release during the oxidation process. As binder materials evolve off the matrices, most of the organic byproducts are destroyed by the high temperatures in the start-up gases. Those trace materials which are not destroyed are consumed in a catalyst section built into the Heat Recovery Unit. 
The initial heat up was begun in March, 1996, but was aborted early due to the premature opening of pressure relief panels in the stack submodules. The panels were replaced by panels of a different design, which needed to be manufactured by the vendor, pushing the second heatup to April. The heatup was resumed on April 13 1996, and the plant was up to operating temperature by April 22. The catalyst and matrix conditioning were sufficiently controlled, and there were no problems associated with thermal excursions. The initial startup demonstrated that the conditioning operations can be controlled sufficiently to allow the start-up of multiple-stack systems. The initial open circuit voltages (OCV's) for the sixteen stacks are shown in Figure 3.8. The voltages were equal to within $0.5 \%$, with stack voltages of $251+/-1$ Volt. The successful conditioning of these 16 stacks simultaneously was a significant project milestone.

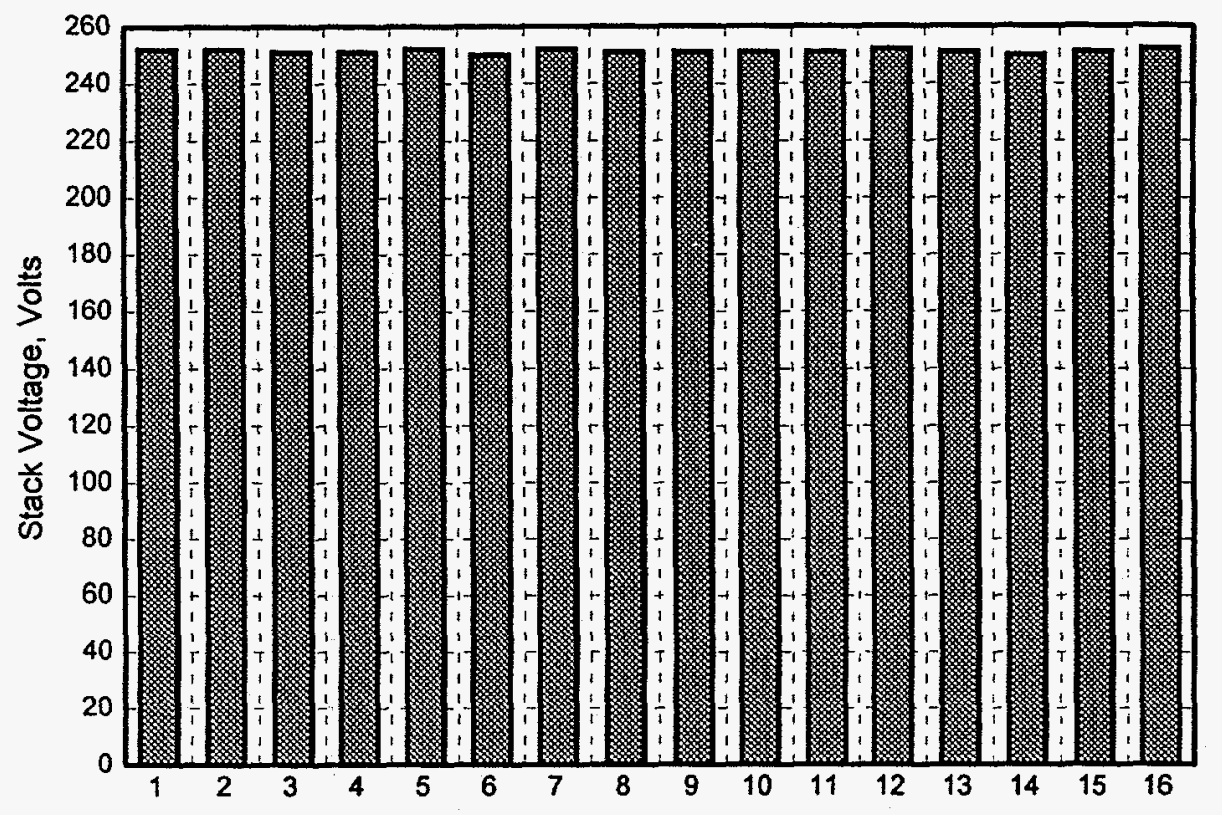

FIGURE 3.8

INITIAL OPEN CIRCUIT VOLTAGES FOR 16 SCDP STACKS

Excellent Voltage Uniformity Confirmed Stack Manufacturing Repeatability and Successful Control of Conditioning Processes. 
Following completion of the initial stack conditioning operations, initiation of grid connect was done with the assistance of representatives from the supplier of the power conditioning unit (PCU). The vendor had noted that since full fuel cell stack voltages had never been imposed on the inverter equipment, additional tuning of the inverter controls was going to be needed. The plant was placed in an operating mode where PCU trips could be tolerated while the tuning was performed. PCU trips were deliberately initiated to verify the plant could ride through such events. The power plant initial power load was established at $200 \mathrm{~kW}$ gross AC power, at 9:04 p.m. on April 24. Inverter monitoring and tuning was done over the next two days at the $200-250 \mathrm{~kW}$ point. Ramping beyond the $250 \mathrm{~kW}$ level began on April 26, and was done slowly over several days. An erroneous factory setting in a DC breaker caused the plant to trip off line twice at the $1 \mathrm{MW}$ level. The setting was corrected, the ramp was resumed, and on Thursday, May 2, the plant had reached the design level $2.0 \mathrm{MW}$ gross AC, delivering 1.8 MW net AC to the Santa Clara electric system.

The plant load was held at or above the rated power level over the next two days while efforts were made to characterize the plant operation and improve net efficiency. In the course of this testing, the operating methods continued to center on a conservative approach given the early stage of testing. This included continued operation of the fired section of the Main Burner. This was done to reduce the likelihood of a burner trip and to minimize the impact if an inverter trip occurred (operating the fired section provides additional mass flow through the stacks to maintain thermal equilibrium in the event of a sudden load shed). The Start-Up Burner in the HRU was also kept running. This was required due to observed heat losses in the cathode exhaust leg of the piping (the heat loss issue was later addressed by filling additional gaps which were found under the lagging in the insulation).

Within these limitations the highest efficiency achieved by the power plant was $43.6 \%$ LHV (7820 Btu/kWh). This was achieved at a power output of $1.93 \mathrm{MW}$ net AC to the grid. This is the highest power level achieved with any type of fuel cell system in the U.S. The voltage levels of the sixteen fuel cell stacks continued to be very uniform at this power level, as shown in Figure 3.9. Throughout the ramp up to this power level, the stack performance exceeded the projection used in the plant design calculations, indicating that the target efficiency of $6850 \mathrm{Btu} / \mathrm{kWh}$ would be met once the plant is operated without supplemental firing of the natural gas burners. Figure 3.10 shows the voltage performance of the sixteen stacks up to the maximum power point. Figure 3.11 shows a summary of the power levels produced by the plant since the initial grid connect in the first operational period. 
Page 20

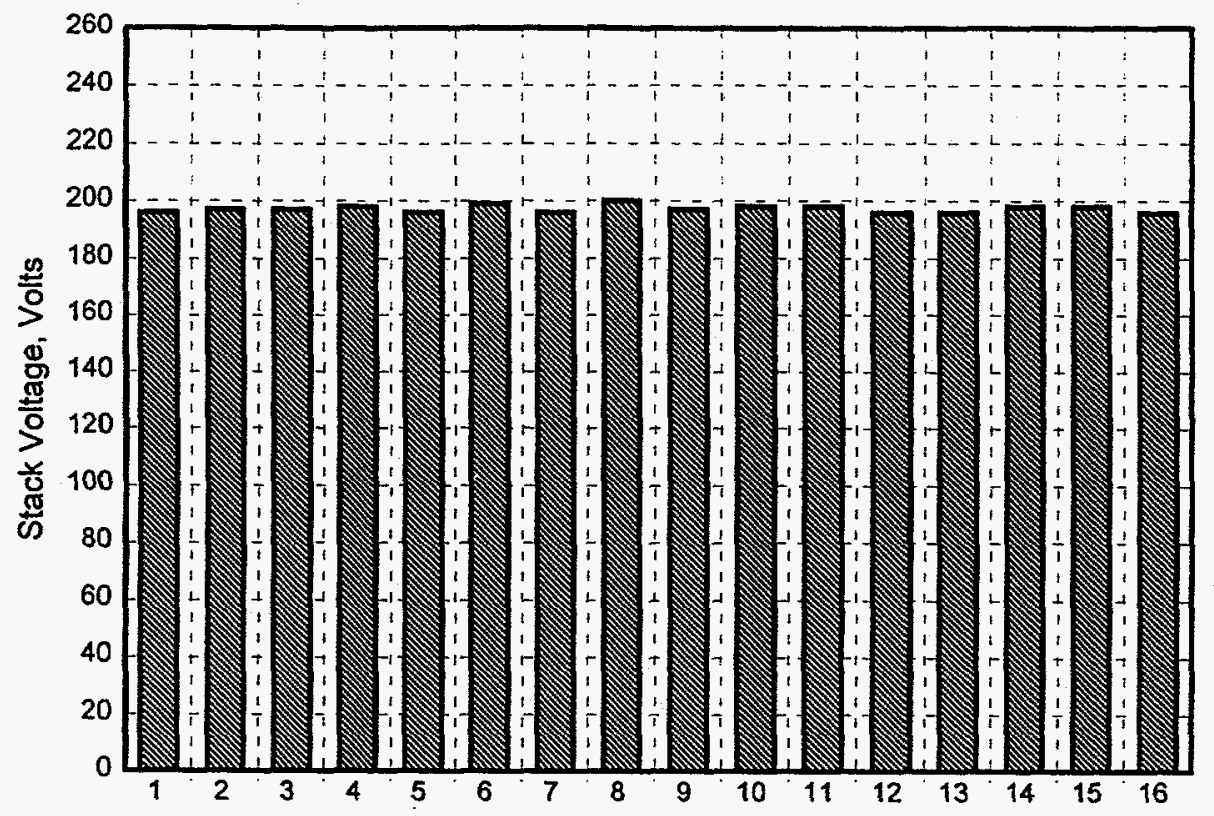

FIGURE 3.9

ON LOAD VOLTAGES FOR 16 SCDP STACKS AT 1.93 MW NET AC POWER Excellent Voltage Uniformity Continued to be Observed at High Power Levels

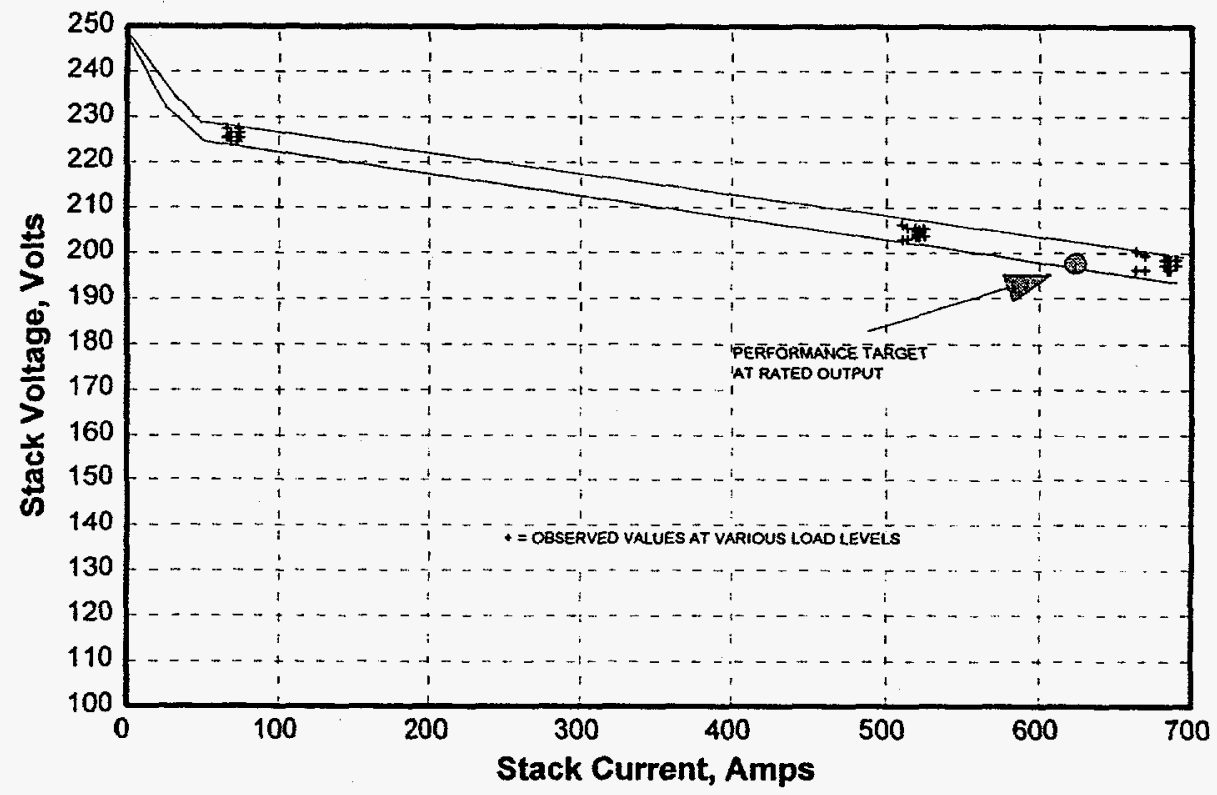

FIGURE 3.10

VOLTAGE PERFORMANCE OF 16 SCDP STACKS OVER LOAD RANGE Individual Stack Performance Curves Met or Exceeded Design Target 
Page 21

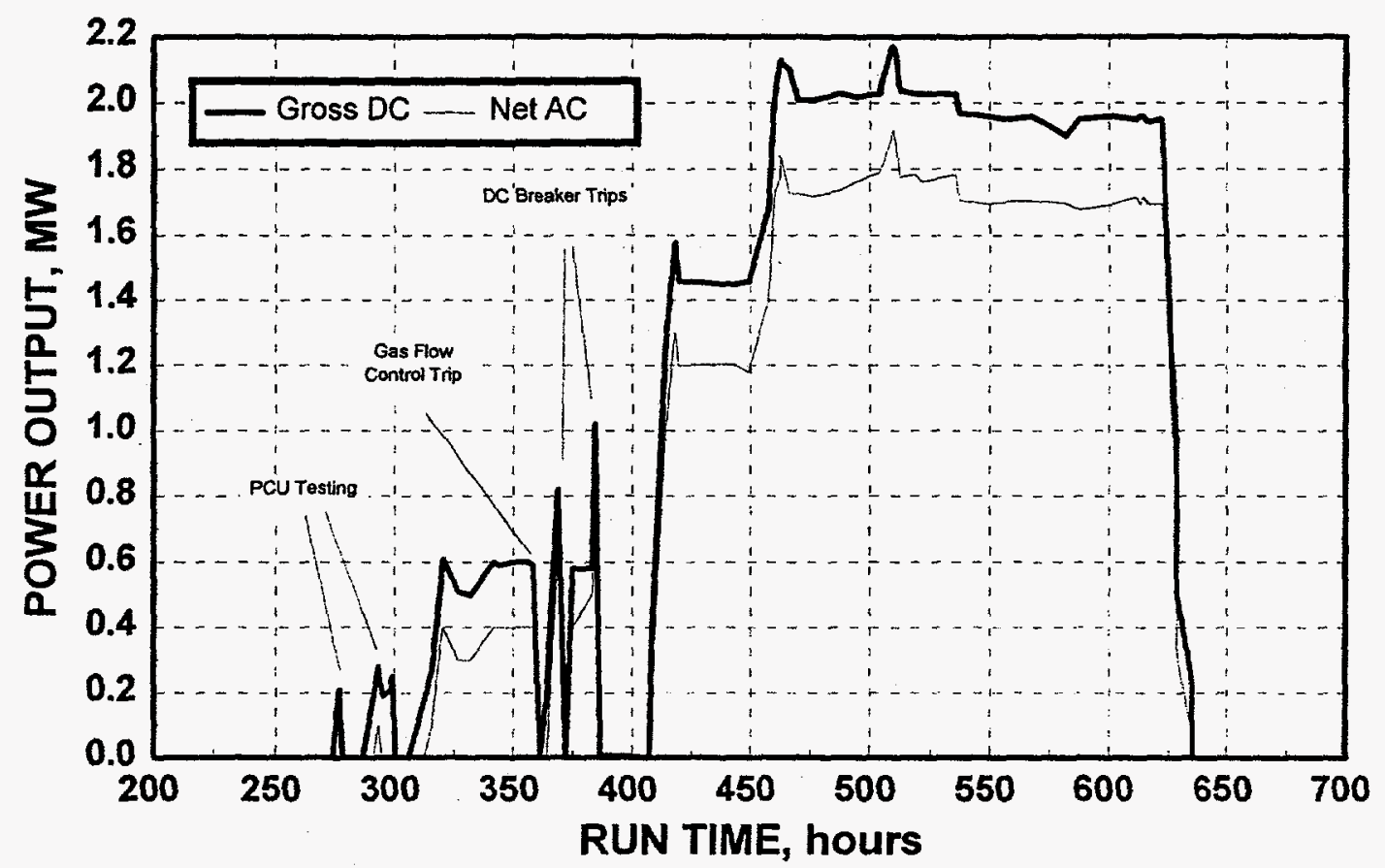

FIGURE 3.11

SCDP POWER PRODUCTION IN FIRST OPERATIONAL PERIOD

Rated Power Was Met and Exceeded After the Initial Startup Period

Beginning approximately 520 hours into the plant operation, intermittent anomalies were observed in some of the stack voltages. These were typically brief dips in stack voltage indicative of external shorting to ground. In some cases the events were associated with an increase in stack enclosure purge flow requirements, indicating that damage was done to gas flow components, resulting in nitrogen leaking into the system. In order to determine the cause of these events, the power plant was shut down and by May 15 had been cooled to ambient temperature for inspection. A total of just over 720 hot operating hours had been logged at the time of this first plant shutdown.

Upon inspection, the cause of the voltage anomalies was determined to be parasitic electrical circuits, caused by a breach of the electrical isolation between the fuel cell stacks and the gas distribution piping. The source of these circuits was traced to a construction aid material used to install the thermal insulation around the fuel cell stacks. At elevated operating temperatures the construction aid material became electrically conductive, diminishing the effectiveness of dielectrics used to isolate fuel and air metal pipes from the fuel cells. Since differential voltages can reach 1000 VDC 
Page 22

in the power plant, it became possible for stray parasitic currents to flow through the tainted dielectrics.

The sixteen stacks in the system are arranged in a series/parallel electrical circuit in which the voltage of each stack relative to ground varies depending on its position in the circuit. The highest voltage stack in each string exhibited damage indicative of electrical arcing across the pipe dielectrics. None of the other stacks in the system exhibited arcing damage, although all of the stacks had tainted pipe dielectrics.

The power plant was restored to service following a repair effort which involved replacing components which had been damaged, and removing the contaminant from those components that had not been damaged. This repair effort was done through the months of June and July, 1996. In addition to the stack electrical repair effort, BOP maintenance work was also done during the outage (instrument recalibration, routine boiler and diesel generator maintenance, etc).

The power plant restart was initiated on August 6, when the stack heatup process was begun. The runtime clock on the plant was reset at 722 hours, which counted the operating time in the previous run (including the cool-down time), but not the down time during the dielectric repair effort. On August 13, the stacks were put on load at the initial grid connect level of $200 \mathrm{~kW}$. The initial performance of the stacks following the thermal cycle taken to perform the repair and maintenance work was good with the exception of stacks 1 and 16, which operated below design levels, but not enough to significantly limit the power plant output. The series/parallel configuration of the stacks allows for a certain amount of load shedding from weak stacks to stronger stacks. It was believed that this flexibility would have allowed operation at full rated load, despite the fact two of the stacks were somewhat weak.

Beginning about 24 hours into the on-load operation, the performance of Stack 6 began to decay. The performance of the stack decayed over the next 24 hours, leveling off at a point where its voltage had dropped 17 volts and it had shed most of its share of the current load to other stacks. The weak performance of this stack limited the initial power ramp activities. By 1660 hours runtime the plant had been ramped to a power output of $1.0 \mathrm{MW}$ net $A C$ to the grid (1.23 MW gross DC). The plant was run at this level for about 12 hours, at which point the performance of weak stacks in the system precluded further ramping. It was observed that all of the stacks operating below design levels shared a common position in the electrical circuit, and a review of the plant operating data (and data collected during ERC's technology development program) led to a possible explanation for performance of these stacks. 
It was observed that during the pipe dielectric shorting which forced the first plant shutdown, the voltages of the shorted pipe and stack hardware in the affected area of the circuit could have been driven to levels which could trigger electrical damage at the stacks. It has been concluded that this probably occurred, leaving residual damage which became progressively worse during the second operational run. The eight stacks in the unaffected portion of the circuit would not incur this problem, and all eight were observed to operate well. Based on these observations, a decision was made to reconfigure the plant and operate the system with the eight stacks in the unaffected portion of the electrical circuit.

Isolation of the desired stacks was done by installing blinds midway down the run of the flow headers. This eliminated the eight stacks at the four ends of the piping system, preserving a symmetrical flow configuration which is important in maintaining a uniform pressure profile throughout the stacks. The mechanical reconfiguration was done in a 10 hour operation, during which time the stacks were not delivered any gas flows. At the end of this reporting period, the mechanical reconfiguration was complete, and the test program was scheduled to resume after the installation of an additional transformer between the inverter and the grid to allow the lower voltage output of the reconfigured power plant to interface with the City's electrical system.

\subsection{SUMMARY}

The demonstration project conducted in this Cooperative Agreement has established a number of important milestones. The Santa Clara Demonstration Plant is the world's first large scale fuel cell demonstration plant to actually deliver its rated power output. The project has demonstrated that a megawatt scale DFC plant can be configured using skid mounted BOP equipment and truck-shipped multi-stack submodules, and that a multiple stack system can be started and operated with excellent performance and uniformity among the stacks.

The operating staff used at the plant consists of locally hired power plant operators. While the plant is manned around the clock, the operation of the plant under automatic control was verified. Even the initial conditioning startup was performed by inputting temperature ramp rate setpoints and allowing the DCS to control the heatup of the plant. Power ramping is done in a similar way, by inputting a power setpoint and a ramp rate and allowing the DCS to control the power ramp and manage the changing process parameters during the ramp. 
The operation levels achieved by all sixteen stacks prior to the onset of the pipe dielectric problem (and the current performance levels for the eight stacks currently in service) indicate that the efficiency criteria for the power plant had the potential of being met once the system was operated without supplemental natural gas fuel.

The SCDP balance of plant has proven to be exceptionally reliable. The number of BOP trips encountered during the initial start-up was minimal, and what few trips did occur were related to issues which could not be evaluated in the pre-test effort. The plant has operated for several months since the initial start-up without additional BOP trips. The system has been shown to ride through minor grid disturbances and respond to major grid problems exactly as intended. The excellent performance of the BOP is an indication that the reliability targets for the DFC technology are potentially achievable. 